\title{
A state-of-art review on activity-based costing
}

\author{
Tahereh Khodadadzadeh*
}

Department of Industrial Engineering (Digital Unit), Iran University of Science \& Technology, Tehran, Iran

\begin{tabular}{l}
\hline C H R O N I C L E \\
\hline Article history: \\
Received June 5, 2015 \\
Received in revised format \\
August 162015 \\
Accepted December 32015 \\
Available online \\
December 32015 \\
\hline Keywords: \\
Activity-based costing \\
Performance measurement \\
Time driven activity-based \\
costing
\end{tabular}

A B S T R A C T

Activity-based costing $(\mathrm{ABC})$ is a method, which identifies activities in a firm and assigns the expenses of each activity with resources to all products and services based on the real consumption by each. This method allocates more overhead costs into direct expenses compared with conventional method. ABC method is normally used for costing as well as monitoring different activities, which involves tracing resource consumption. This paper presents a survey on advances of $\mathrm{ABC}$ based method. The study has discussed the advantages and disadvantages of the implementation of $\mathrm{ABC}$ based method in different industries. The survey also discusses recent advances on time driven $\mathrm{ABC}$ method in health care industries.

\section{Introduction}

Activity-based costing $(\mathrm{ABC})$ is a method, which identifies activities in a firm and assigns the expenses of each activity with resources to all products and services based on the real consumption by each (Drury, 1992; Cokins, 1996, 2002; Cohen, 2000). This method allocates more overhead costs into direct expenses compared with conventional method. ABC method is normally used for costing as well as monitoring different activities, which involves tracing resource consumption (Cooper, 1990, 1992). Resources, in this method, are categorized into different activities, and activities are divided into various cost objects according to consumption estimates (Kaplan, 1992; Everaert \& Bruggeman, 2007). The implementation of ABC method helps identify and remove products and services, which are unprofitable and possibly adjust the prices of the products and services, which are overpriced (Lewis, 1995; Emblemsvåg \& Bras, 2012). It also helps detect and get rid of production or service processes, which are ineffective and assign processing concepts that lead to a better yield. ABC is normally applied as a technique for learning more about product and customer cost and profitability according to the

* Corresponding author. Tel: +9877240129

E-mail address: takhodadadzadeh@mail.com (T. Khodadadzadeh) 
production or performing processes (Swenson, 1995). Therefore, ABC has been implemented to make strategic decisions such as pricing, outsourcing, identification and measurement of process improvement initiatives (Greenwood, \& Reeve, 1992).

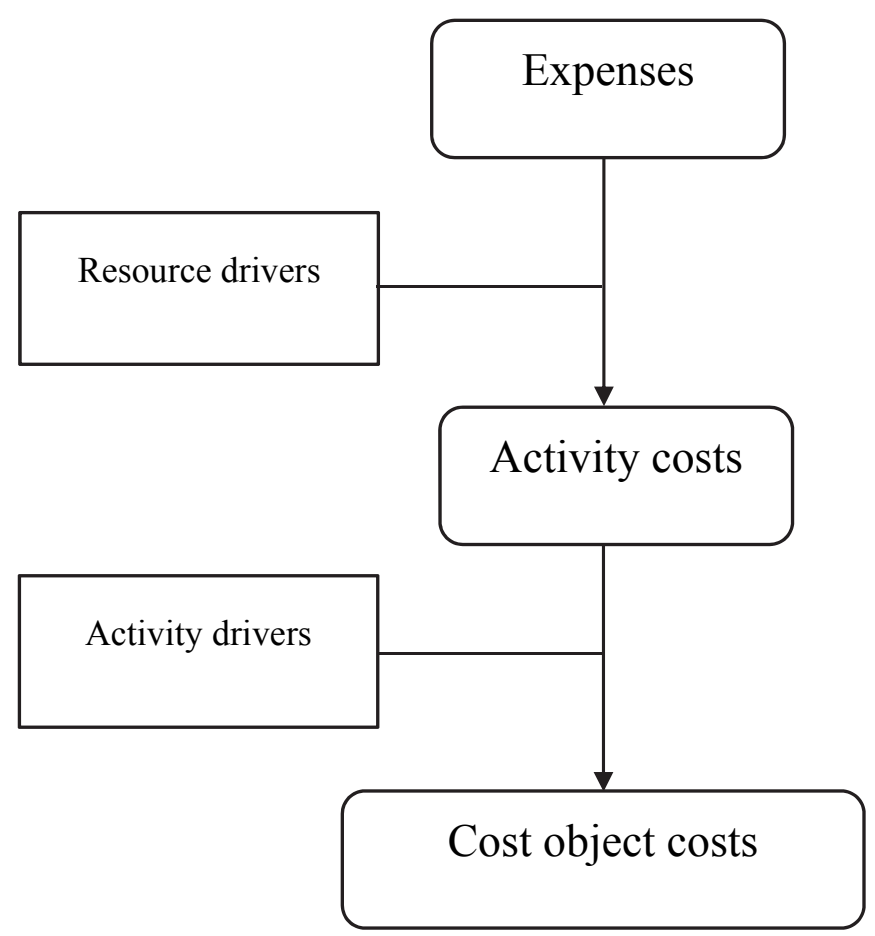

Fig. 1. The structure of $\mathrm{ABC}$

ABC systems categorize overhead costs into multiple cost pools and activity measures may trace these expenses to products (See Fig. 1). We may create a cause and effect relationship between different activities and resource consumption, which helps product costing as well as cost control efforts (Swenson, 1995; Kock, 1995). There are several cases of successful implementation of ABC method (Bras \& Emblemsvag, 1995; Ong, 1995; Foster \& Swenson, 1997; Goddard \& Ooi, 1998; Greene \& Metwalli, 2000; Anderson, 2002; Tornberg, 2002; Chan, 2003; Lievens et al., 2003; Tsai et al., 2014; Kaplan et al., 2015; Shigaev, 2015). One of the primary concerns on implementation of ABC method is to select appropriate cost drivers (Babad \& Balachandran, 1993) and many people have tried to use multiple criteria decision making techniques to detect efficient cost drivers.

This paper reviews some of the recent advances on the implementation of $\mathrm{ABC}$ based systems and discusses the advantage/disadvantages of the $\mathrm{ABC}$ usage.

\section{Literature review}

Schniederjans and Garvin (1997) applied the analytic hierarchy process (Saaty, 2003, 2004) and multiobjective programming for the selection of cost drivers in ABC. Beheshti (2004) discussed competitive advantage with ABC management system. Bras and Emblemsvag (1995) used ABC model in design for demanufacture under the presence of uncertainty. Demanufacture, in their survey, was also defined as the process opposite to manufacturing involved in recycling materials and product components after a product taken back by a firm. The crux in developing an ABC model was to determine the activities, which would be present in the demanufacturing process of a product, and afterwards assign reliable cost drivers and associated consumption intensities to the activities. 
Degraeve et al. (2005) explained that ABC could not be considered as an optimization tool as such, but it may give some important accurate input to the optimizing mathematical program, whereas many mathematical models only takes into account only variable costs. They also explained that the integration of both $\mathrm{ABC}$ and mathematical models could yield better results in the setting of many problems. Shigaev (2015) explained the case of the realization of the two-stage cost allocation scheme of $\mathrm{ABC}$ in Russian accounting system implemented at a distribution company. They provided the case of preparation of accounting entries for $\mathrm{ABC}$ and associated customer profitability report at a distribution company. Tsai et al. (2014) used ABC decision model for life cycle assessment in green building projects.

Ben-Arieh and Qian (2003) provided a method of applying ABC to make an assessment on the cost of the design and development activity for machined parts. McGowan and Klammer (1997) investigated employees' satisfaction with $\mathrm{ABC}$ implementation for four firms. In their survey, user involvement for the implementation of the quality of information produced by the systems was associated with employees' satisfaction on ABC implementation. Chenhall (2004) discussed the role of cognitive and affective conflict in early implementation of ABC management. Qian and Ben-Arieh (2008) presented a cost-estimation technique, which links $\mathrm{ABC}$ with parametric cost representations of the design and development phases of machined rotational parts. Greene and Metwalli (2000) analyzed, evaluated and compared two different scenarios of acquiring capital equipment and explained the importance of utilizing the $\mathrm{ABC}$ method in making a sound financial decision as compared with the traditional cost method.

Goddard and Ooi (1998) investigated the development of ABC in university accounting and evaluated the contribution it might make for solving the issues associated with central overhead cost allocation systems. They developed a case study based on ABC methodology and applied it to library services at the University of Southampton. Their results indicated substantial differences in the allocation of the central overhead expenses. They, however, argued that although the ABC approach could overcome some of the problems of overhead allocation and improved the economic efficiency of organizations, there were significant trouble with its practical application. Ellis-Newman and Robinson (1998) also reported the same issues in applying $\mathrm{ABC}$ method in library cost accounting. In fact, despite the advantages of $\mathrm{ABC}$ method, some people argue that we may forget about the other aspects of products and services when we look for financial characteristics. Dolinsky and Vollmann (1991), for instance, argued that companies that an over emphasis on product costing may disregard the importance of applying non-financial performance measures. Noreen (1991) provided certain conditions under which ABC systems provide relevant costs. According to Cooper and Kaplan (1991) "ABC is a powerful tools but only if managers resist that instinct to view expenses at the unit level".

\subsection{Time driven activity-based costing}

Time driven activity-based costing (TDABC) measures costs directly from clinical and administrative processes implemented in patient care, thereby giving precious information for process improvements. TDABC appears to be more accurate and simpler than traditional ABC because it assigns resource expenses to patients according to the amount of time clinical and staff resources used in patient encounters. Other costing methods apply somewhat arbitrary allocations that give little insight into the actual clinical processes implemented to treat medical conditions. TDABC has been successfully implemented in European and US health-care settings to help process improvements and new reimbursement methods, but it has not been implemented in resource-limited settings (Mandigo et al., 2015). Mandigo et al. (2015) aimed to optimize TDABC in a resource-limited setting to provide precise procedure and service expenses, reliably predict financing requirements, inform quality improvement initiatives, and maximize efficiency.

McLaughlin (2014) explained the use experiment, share lessons learned across the care continuum, and report how TDABC has actively engaged health care providers in estimating expense activities and care redesign. Shu et al. (2014) explored the opportunity to improve the hospital cost accounting system 
with TDABC model. They took routine examination services in CT16 department of a public hospital as cost objects, to estimate the expenses and advantages of the services and the efficiency of resources by applying TDABC. They concluded that TDABC could not only improve the level of hospital cost management, but also it could provide useful references and scientific basis for the formulation and revision of medical service charges and other advanced medical payments.

\section{Summary}

The survey has indicated that while the implementation of $A B C$ systems is time consuming and requires cooperation from different parts of organization, it may help organizations find cost components. The implementation of $\mathrm{ABC}$ method helps identify and remove products and services, which are unprofitable and possibly adjust the prices of the products and services, which are overpriced. Recently, there is an increasing trend on using time driven $\mathrm{ABC}$ system especially in hospitals. This methods measures costs directly from clinical and administrative processes implemented in patient care, thereby giving precious information for process improvements. We hope this survey could motivate other interested researchers to do more research on TDABC.

\section{Acknowledgement}

The authors would like to thank the anonymous referees for constructive comments on earlier version of this paper.

\section{References}

Anderson, S. W. (2002). A framework for assessing cost management system changes: the case of activity-based costing implementation at General Motors, 1986-1993. Citable URI: http://hdl.handle.net/1721.1/1637.

Babad, Y. M., \& Balachandran, B. V. (1993). Cost driver optimization in activity-based costing. Accounting Review, 68(3), 563-575.

Beheshti, H. M. (2004). Gaining and sustaining competitive advantage with activity based cost management system. Industrial Management \& Data Systems, 104(5), 377-383.

Ben-Arieh, D., \& Qian, L. (2003). Activity-based cost management for design and development stage. International Journal of Production Economics, 83(2), 169-183.

Bras, B., \& Emblemsvag, J. (1995, September). The use of activity-based costing, uncertainty and disassembly action charts in demanufacture cost assessments. In ASME Advances in Design Automation Conference, Sept (pp. 17-20).

Chan, Y. C. L. (1993). Improving hospital cost accounting with activity-based costing. Health Care Management Review, 18(1), 71-77.

Chenhall, R. H. (2004). The role of cognitive and affective conflict in early implementation of activitybased cost management. Behavioral Research in Accounting, 16(1), 19-44.

Cokins, G. (1996). Activity-based Cost Management: making it Work. Irwin.

Cokins, G. (2002). Activity-based cost management: an executive's guide (Vol. 10). John Wiley \& Sons.

Cohen, M. D., Hawes, D. R., Hutchins, G. D., McPhee, W. D., LaMasters, M. B., \& Fallon, R. P. (2000). Activity-Based Cost analysis: A method of analyzing the financial and operating performance of academic radiology departments. Radiology, 215(3), 708-716.

Cooper, R. (1990). Implementing an activity-based cost system. Journal of Cost Management, 4(1), $33-42$.

Cooper, R., \& Kaplan, R. S. (1991). Profit priorities from activity-based costing.Harvard Business Review, 69(3), 130-135.

Cooper, R. (1992). Implementing activity-based cost management: moving from analysis to action: implementation experiences at eight companies. Inst of Management Accountants. 
Degraeve, Z., Labro, E., \& Roodhooft, F. (2005). Constructing a total cost of ownership supplier selection methodology based on activity-based costing and mathematical programming. Accounting and Business Research, 35(1), 3-27.

Dolinsky, L. R., \& Vollmann, T. E. (1991). Transaction-based overhead considerations for product design. Journal of Cost Management, 4(2), 7-19.

Drury, C. (1992). Activity-based costing (pp. 273-288). Springer US.

Ellis-Newman, J., \& Robinson, P. (1998). The cost of library services: Activity-based costing in an Australian academic library. The Journal of Academic Librarianship, 24(5), 373-379.

Emblemsvåg, J., \& Bras, B. (2012). Activity-based Cost and Environmental Management: A Different Approach to ISO 14000 Compliance. Springer Science \& Business Media.

Everaert, P., \& Bruggeman, W. (2007). Time-driven activity-based costing: exploring the underlying model. Journal of cost management, 21(2), 16-20.

Foster, G., \& Swenson, D. W. (1997). Measuring the success of activity-based cost management and its determinants. Journal of Management Accounting Research, 9, 109.

Goddard, A., \& Ooi, K. (1998). Activity-based costing and central overhead cost allocation in universities: a case study. Public Money and Management,18(3), 31-38.

Greene, J. K., \& Metwalli, A. (2000). The impact of activity based cost accounting on health care capital investment decisions. Journal of health care finance, 28(2), 50-64.

Greenwood, T. G., \& Reeve, J. M. (1992). Activity-based cost management for continuous improvement: a process design framework. Journal of Cost Management, 5(4), 22-40.

Kaplan, R. S. (1992). In defense of activity-based cost management. Strategic finance, 74(5), 58.

Kaplan, A. L., Agarwal, N., Setlur, N. P., Tan, H. J., Niedzwiecki, D., McLaughlin, N., ... \& Saigal, C. S. (2015, March). Measuring the cost of care in benign prostatic hyperplasia using time-driven activity-based costing (TDABC). Healthcare, 3(1), 43-48.

Kock, S. (1995). Implementation considerations for activity-based cost systems in service firms: the unavoidable challenge. Management Decision,33(6), 57-63.

Lievens, Y., Van den Bogaert, W., \& Kesteloot, K. (2003). Activity-based costing: a practical model for cost calculation in radiotherapy. International Journal of Radiation Oncology Biology Physics, 57(2), 522-535.

Lewis, R. J. (1995). Activity-based models for cost management systems. Greenwood Publishing Group.

Mandigo, M., O'Neill, K., Mistry, B., Mundy, B., Millien, C., Nazaire, Y., ... \& Kaplan, R. (2015). A time-driven activity-based costing model to improve health-care resource use in Mirebalais, Haiti. The Lancet, 385, S22.

McGowan, A. S., \& Klammer, T. P. (1997). Satisfaction with activity-based cost management implementation. Journal of Management Accounting Research, 9, 217.

McLaughlin, N., Burke, M. A., Setlur, N. P., Niedzwiecki, D. R., Kaplan, A. L., Saigal, C., ... \& Kaplan, R. S. (2014). Time-driven activity-based costing: a driver for provider engagement in costing activities and redesign initiatives.Neurosurgical focus, 37(5), E3.

Noreen, E. (1991). Conditions under which activity-based cost systems provide relevant costs. Journal of Management Accounting Research, 3(4), 159-168.

Ong, N. S. (1995). Manufacturing cost estimation for PCB assembly: An activity-based approach. International Journal of Production Economics, 38(2), 159-172.

Qian, L., \& Ben-Arieh, D. (2008). Parametric cost estimation based on activity-based costing: A case study for design and development of rotational parts.International Journal of Production Economics, 113(2), 805-818.

Saaty, T. L. (2003). Decision-making with the AHP: Why is the principal eigenvector necessary. European journal of operational research, 145(1), 85-91.

Saaty, T. L. (2004). Decision making - the analytic hierarchy and network processes (AHP/ANP). Journal of systems science and systems engineering,13(1), 1-35. 
Schniederjans, M. J., \& Garvin, T. (1997). Using the analytic hierarchy process and multi-objective programming for the selection of cost drivers in activity-based costing. European Journal of Operational Research, 100(1), 72-80.

Shigaev, A. (2015). Accounting entries for activity-based costing system: The case of a distribution company. Procedia Economics and Finance, 24, 625-633.

Shu, F., Weidong, Z., Zhuo, L. Z., Haibin, C., \& Yaohui, Z. (2014). The application of time driven activity-based costing in fine cost management of the hospital. Jiangsu Healthcare Administration, 6, 063.

Swenson, D. (1995). The benefits of activity-based cost management to the manufacturing industry. Journal of Management Accounting Research, 7, 167.

Tornberg, K., Jämsen, M., \& Paranko, J. (2002). Activity-based costing and process modeling for costconscious product design: A case study in a manufacturing company. International Journal of Production Economics, 79(1), 75-82.

Tsai, W. H., Yang, C. H., Chang, J. C., \& Lee, H. L. (2014). An Activity-Based Costing decision model for life cycle assessment in green building projects.European Journal of Operational Research, 238(2), 607-619. 